\title{
Possible directions for using bran in heat-power engineering
}

\author{
Maria Gaydabrus ${ }^{1, *}$, Igor Razov ${ }^{2}$, Roman Tabakaev $^{1}$, and Vitaly Lebedev ${ }^{3}$ \\ ${ }^{1}$ National Research Tomsk Polytechnic University, 634050 Tomsk, Russia \\ ${ }^{2}$ Tyumen industrial University, 625000 Tyumen, Russia \\ ${ }^{3}$ Omsk State Transport University, 644046 Omsk, Russia
}

\begin{abstract}
In connection with the necessity of providing of ecofriendlyness of energy the researches sent to the increase of stake of biomass in fuel and energy balance are actual direction of science and technique. The aim of work is put the study of heating engineering properties of bran and research of possibility of briquetting as it applies to the power use in the stratified fire-box devices. Research methods included standard methodologies of ISO and physical experiment. It is shown as a result of research that bran on the warmth of combustion is comparable with brown coals, but has a less ash-content considerably. However shallow factious composition of bran and caking in the process of ashing will result in high operating costs at their incineration in a natural kind. The variant of the power use of bran is considered as the preforms got the thermal pressing, and the optimal temperature of pressing, equal $150^{\circ} \mathrm{C}$. On the example of pressing of shell of cedar nuts possibility of the use of bran is shown as connective, is set here.
\end{abstract}

\section{Introduction}

Bran is a by-product of flour-miller production as a hard shell of grain and, in fact, is departure of food industry. They found the application as feed addition for agricultural animals and bird. However, according to [1] bran serves only as a supplement and cannot completely replace the existing diet. The folded situation results in the market entry of surplus amount of bran, compelling to search the alternative ways of their use.

The aim of work is put the study of heating engineering properties of bran and research of possibility of briquetting as it applies to the power use in the stratified fire-box devices.

\section{Material and methods}

Bran (Fig. 1) is considered, wheats got at processing one of enterprises of the Kemerovo region. Bran had heterogeneous factious composition: the stake of bran made $14.1 \%$ sizes a more than $1 \mathrm{~mm}$; $0.5-1.0 \mathrm{~mm}-38.6 \%$; $0.2-0.5 \mathrm{~mm}-35.9 \%$; less than $0.2 \mathrm{~mm}-11.4 \%$. Before an analysis bran is preliminary dried up at a room temperature to an air-dry state.

\footnotetext{
* Corresponding author: maria.lazy597@gmail.com
} 


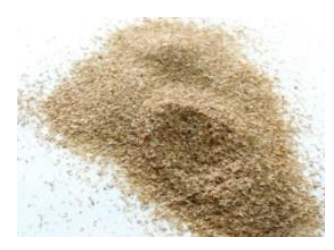

Fig. 1. Prospected bran.

Heating engineering descriptions of bran, certain concordantly ISO 5068-1:2007, ISO 1171:2010, ISO 5071-1:3013, presented in a Table. 1. The value of lower heating and ultimate analysis are set on a high-fidelity analytical equipment - calorimeter of ABK-1 (Russia) and analyzer of Vario Micro Cube (Germany) accordingly.

Table 1. Peat characteristics.

\begin{tabular}{cccccccccr}
\hline Peat & $\begin{array}{c}\text { Moisture } \\
\text { content } \\
W^{a}, \%\end{array}$ & $\begin{array}{c}\text { Dry ash } \\
\text { content } \\
A^{d}, \%\end{array}$ & $\begin{array}{c}\text { Volatile } \\
\text { yield } \\
V^{\text {daf }}, \%\end{array}$ & $\begin{array}{c}\text { Lower } \\
\text { heating } \\
\text { value } Q_{i}^{r}, \\
\mathrm{MJ} / \mathrm{kg}\end{array}$ & \multicolumn{2}{c}{$C^{\text {daf }}$} & $H^{\text {daf }}$ & $N^{\text {daf }}$ & \multicolumn{2}{c}{$S^{\text {daf }}$} & $O^{\text {daf }}$ \\
\hline Bran & 11.5 & 5.9 & 81.0 & 16.6 & 48.44 & 6.92 & 3.05 & - & 41.59 \\
\hline
\end{tabular}

Bran has a high enough ash content $\left(A^{d}=5.9 \%\right)$ for biomass. Lower heating value $\left(Q_{i}^{r}=16.6 \mathrm{MJ} / \mathrm{kg}\right)$, comparable with the lower heating of row of brown coals [2], allows to examine bran as a fuel for caldron options. A non-flying remain appearing after determination of volatile yield had the alloyed character (Fig. 2).

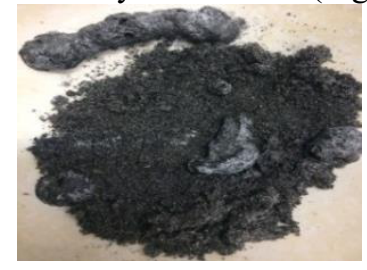

Fig. 2. Non-flying remain appearing after determination of volatile yield from bran.

\section{Results and discussion}

Taking into account the volumes of exit of bran as wastes (a few tons in twenty-four hours within the limits of only one enterprise), the possible sphere of their power use is see a domestic economy, objects of small energy or coverage of own power expenses of enterprise. An in this case comburent equipment as it applies to that it is needed to examine bran are hot-water boilers with the fire-box devices of the stratified type. By analogy with peat transportation of bran on distance a more than 25-30 kilometres will promote their cost considerably [3] and, probably, will do uncompetitive as compared to other types of fuel.

As it applies to this type of equipment the factious composition of bran given above will result in the high size of failure through a furnace-bar grate. What be more, simultaneously with it in the process of incineration there will be caking of chark remain, hampering work of blow fans and reducing efficiency of burning, that in totality will result in low outputinput ratio options and to the high operating costs.

In connection with above-stated by one of perspective directions of processing of bran for the subsequent power use, briquetting can be examined [4].

Possibility of the cold briquetting of bran is considered at a room temperature with the receipt of preform sizes concordantly GOST 54248-2010 at pressure 5-15 MPa. But to form 
durable preforms this character not succeeded: preforms collapsed in the process of extraction from a press-form.

The thermal briquetting of bran was investigational at pressure $10 \mathrm{MPa}$ (mean value from the considered range at the cold briquetting). A temperature of briquetting was 100$180^{\circ} \mathrm{C}$. On a Fig. 3 the preforms got here are shown.

A preform (Fig. 4) also had a durable protective layer, stability to the abrasion and destruction.

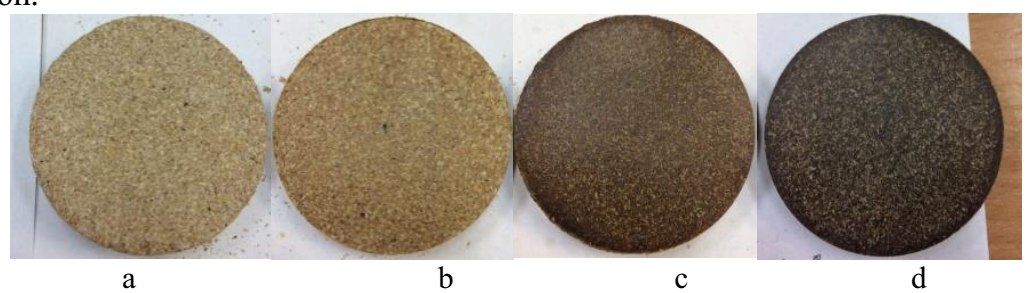

Fig. 3. Preforms got the thermal pressing bran (a diameter is a $50 \mathrm{~mm}$ ): a) $-100^{\circ} \mathrm{C}$, b) $-125^{\circ} \mathrm{C}$, c) $\left.-150^{\circ} \mathrm{C}, \mathrm{d}\right)-180^{\circ} \mathrm{C}$.

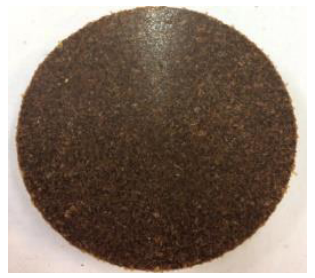

Fig. 4. Preform from bran and shell of cedar nuts, got pressing at $150^{\circ} \mathrm{C}$.

\section{Conclusions}

Bran on the lower heating value is comparable with brown coals, but has less dry ash content considerably. However shallow factious composition of bran and caking in the process of ashing will result in high operating costs at their incineration in a natural kind.

Possibility of the power use of bran is shown as the preforms got the thermal pressing. Thus the optimal temperature of pressing is $150^{\circ} \mathrm{C}$.

Bran it maybe to use as connective at making of mixed preforms.

The optimization of the combustion of fuels based on coal and oil processing waste was performed within the framework of the strategic plan for the development of National Research Tomsk Polytechnic University as one of the world-leading universities.

\section{References}

1. E.B. Etuk, A.V.Ifeduba, U.E. Okata, I. Chiaka, Okoli, C. Ifeanyi, N.J. Okeudo, B.O. Esonu, A.B.I. Udedibie, J.C. Moreki, J Anim Sci Adv. 2, 510 (2012).

2. D.F. Umar, H. Usui, B. Daulay, Fuel Process. Technol. 87, 1007 (2006).

3. V.I. Markov, N.I. Volkova, Ecology and industry in Russia, 1, 58 (2014) [in Russian].

4. R. Tabakaev, I. Shanenkov, A. Kazakov, A. Zavorin, J. Anal. Appl. Pyrolysis, 124, 94 (2017) 